\title{
DETERMINING SOUTH AFRICAN CONSUMERS' WILLINGNESS TO PAY FOR CERTIFIED KAROO LAMB: AN APPLICATION OF AN EXPERIMENTAL AUCTION
}

\author{
K. van Zyl*, H. Vermeulen** and J.F. Kirsten***
}

\author{
*Masters student, Department of Agricultural Economics, Extension and Rural Development \\ University of Pretoria. Email: karlienvz@GWK.co.za \\ **Agricultural Economist, Bureau for Food and Agricultural Policy (BFAP). Email: hes.vermeulen@gmail.com \\ ***Head: Department of Agricultural Economics, Extension and Rural Development \\ University of Pretoria. Email: johann.kirsten@up.ac.za
}

\begin{abstract}
Changes in the features of food demand and consumption have moved from the mass consumption model towards an increasing qualitative differentiation of products and demand. This movement towards addressing consumers' demand for food products with more advanced quality attributes has led to increasingly complex food qualification processes and a proliferation of standards. Accompanying these changes in the agro-food system is a growing consumer concern for food safety and quality. One important attribute of 'quality' is the origin of a food product. This paper focuses on lamb originating from Karoo region of South Africa and tests consumers' willingness to pay a premium for this specific origin attribute of the product. A random nth price auction was conducted to obtain willingness to pay estimates for a premium on a $500 \mathrm{~g}$ packet of certified Karoo lamb loin chops. Various demographic and behavioural variables were linked to participants' individual bids in order to determine the possible influence of these variables on participants' bidding behaviour. A general positive willingness to pay for certified Karoo lamb was observed, with an average premium of $R 21.80 / \mathrm{kg}$ recorded for loin chops. The impact of additional information was clearly visible as bids increased substantially after additional information regarding the product was introduced.
\end{abstract}

JEL Classification Codes: Agricultural Markets and Marketing; Origin based foods; Experimental Auction; Willingness-to-Pay 


\section{Introduction}

The agro-food system has rapidly evolved worldwide in the last few decades (Padberg, Ritson \& Albisu, 1997) with marketing and quality control shifting from product control to process control, thereby shifting competition in the agro food system (Ponte \& Gibbon, 2005). Concurrently there have been important changes in the features of food demand and consumption moving away from the mass consumption model towards an increasing qualitative differentiation of products and demand (Allaire, 2004). This goes along with the fact that other factors, in addition to price, are gaining more importance in transmitting knowledge about product quality to consumers. Padilla, Villalobos, Spiller \& Henry (2007) explain that consumer preferences for food are defined by changes in demographic and sociocultural variables, consumer attitudes and the development of new lifestyles. These factors are also impacting on competition among actors in the supply chains. This movement towards addressing consumers' demand for food products with more advanced alternative quality attributes (Ponte \& Gibbon, 2005; Krystallis \& Ness, 2005) has led to increasingly complex food qualification processes and a proliferation of standards.

Accompanying these changes in the agro-food system is a growing consumer concern for food safety and quality. This has led to a new market in differentiated, high value food products (Rodriguez, Lupin \& Lacaze, 2006). The demand for these products stimulated a need for change in food technology and distribution. Even though these trends are also permeating the South African landscape, little research has been done on the local quality dynamics.

Quality is a multifaceted concept, which cannot be evaluated as a whole by consumers; therefore consumers use indicators of quality to make a judgement about the product quality (Oude Ophuis \& Van Trijp, 1995). Food choices address a wide range of quality attributes conventional as well as more advanced quality attributes. When consumers are faced with a buying decision, they have an idea of the specific product attributes they desire. Product attributes are a quality or feature of a product. Melton, Huffman, Shogren \& Fox (1996) states that consumers will value similar products differently based on slight differences in product attributes. 
Quality attributes can be categorized as search, experience and credence attributes. Search attributes can be identified immediately and can thus be verified at the time of the purchase (Cunningham, 2003). Search attributes may include product colour, meat cut and packaging material. Experience attributes can only be identified during or after consumption and may include tenderness, taste and product convenience. Credence attributes cannot be objectively evaluated before, during or after consuming the product (Northen, 2000). Credence attributes may include hormone-free or nutritional claims, which are generally certified by a reputable third party, in order to be considered as trustworthy by consumers (Cunningham, 2003).

An important quality attribute of food products is the 'origin' of food which can also be seen as a credence attribute as it cannot be objectively evaluated prior or during consumption of the product; it can only be evaluated if the specific information is given on the product label or in some other way and also through some form of guarantee. The origin of food dimension is well entrenched in the European system of Geographical Indications which are acknowledged as an independent intellectual property right with the signing of the Agreement on Trade Related Aspects of Intellectual Property Rights (TRIPS). Geographical indications stand to protect products that are intrinsically linked to a region based on either their quality, reputation or some other characteristic. With a long history of traditional production, European countries have for centuries recognized and fiercely protected the inherent value captured in the link between a product and its origin. European nations have protected names such as Parmesan, Roquefort, Champagne, Port and Sherry through a system of Geographical Indications to ensure that only people and firms within a specific geographical region benefit from the commercial exploitation of their heritage or their specific resources (Bramley and Kirsten, 2007).

The Karoo region in South Africa resembles many of the attributes of a region with identity, reputation and is a significant part of South African folklore. The images of the Karoo (e.g. windmills and sheep, farm homesteads, endless vistas) are engrained in the minds of many South Africans when they think of the region. Because of these images and the tranquillity and honesty of the Karoo way of life the 'Karoo' concept has become synonymous with quality, tradition and wholesomeness. As a result of these images, people not even remotely linked to the geography or the values and images of the region exploit the word Karoo to make profit. Furthermore, Karoo lamb/mutton has become associated with a unique and desirable flavour, being described as much sought after (Kirsten, 2010). 
In order to protect the geographical name of the Karoo, as well as the indigenous resources associated with Karoo lamb/mutton, the potential exists for the establishment of a Geographical Indication based on the reputation of quality and flavour in combination with the nostalgia generated by the perception of the Karoo region.

The need has arisen to investigate the opportunity to establish a formal certification label for Karoo meat of origin. It is necessary to first establish if there is economic merit in this process by investigating whether consumers are willing to pay a premium for certified sheep meat from the Karoo region in South Africa

It is in this context that the specific objective of this paper is to develop an initial understanding of the willingness by wealthier South African consumers to pay more for meat originating from the Karoo, using a random $n$th price auction mechanism. The paper will in the process also:

- Test the design and implementation of a random $n$th price experimental auction on a food product with advanced quality attributes.

- Test the impact of additional product information on consumers' bidding behaviour for certified Karoo lamb.

- Analyse the possible links between demographic variables, consumer attitudes towards Karoo lamb and consumer bidding behaviour for Karoo lamb.

\section{Methodology}

\subsection{Random nth price auction}

The random $n$ th-price auction was formally introduced by Shogren, Maroglis, Koo, \& List (2001) and combines the features of the Vickrey second-price auction, which encourages competition amongst bidders, and the Becker-DeGroot-Marschak mechanism, which gives all bidders a chance to win the auction (Lusk \& Shogren, 2007).

The key element of the random $n$ th-price auction is a random and endogenous marketclearing price. The randomness of the price ensures that all bidders are engaged, while the endogenous price guarantees that the payment (market-clearing) price is in line with the value 
that the consumer attaches to the product (private value) of the bidders (Shogren, Maroglis, Koo, \& List, 2001)

The standard random $n$ th-price auction works as follows: Each participant would offer a sealed bid for the auctioned product. The monitor collects the bids and sorts them from the highest to the lowest bid. The monitor now randomly draws a number $(n)$ which will be from the distribution 2 to $k$ (with $k$ being the number of participants). The monitor will sell one unit of the good to each of the $(n-1)$ highest bidders at the randomly drawn $n$ th-price (Shogren, Maroglis, Koo, \& List, 2001). These participants are referred to as the winners of the round or auction, because they get to trade in the auction i.e. exchange their original good for the novel good at the payment price (Akaichi \& Gil, 2009). The reason for the distribution starting at 2 to $k$ and not 1 to $k$, is because if the distribution was from 1 to $k$, and the monitor draws $n=1$, then there would be no winners in the auction, seeing as the winners of the auction would be the equal to $n-1$. It is further important to note that the random number $n$ being drawn is a position being drawn and not the actual payment price.

Shogren, Maroglis, Koo, \& List (2001) set out to investigate if the random $n$ th-price auction could engage all bidders to bid truthfully. It was found that each bidder should bid sincerely because they cannot depend on the random market-clearing price as a marker or price indicator. Everyone has an equal chance of winning the auction and purchasing the good because the market-clearing price is determined endogenously - it is drawn from the bids submitted in the auction round and could be any price within the range of bids. The random $n$ th-price auction is further demand revealing because of its natural ability to engage all bidders, even if they believe that they are in the lower tail of the value distribution (List, 2003). The mechanism reengages bidders who have low preferences for a good and believe they cannot win the auction profitably (Shogren, Maroglis, Koo, \& List, 2001).

\subsection{Sample}

The typical sample size of an auction depends on various factors, including financial constraints and the main objectives of the study. The objectives of this type of study can be either to identify differences in valuations between treatments or to provide an estimate of the mean WTP / willingness to accept (WTA) for a specific good. A larger sample would be preferred if the main focus is to evaluate the impact of information treatments (Lusk \& Shrogen, 2007). In general, sample sizes of experimental auctions are relatively small due to 
the expensive nature of this research method as participants have to be recruited and paid participatory fees to attend laboratory sessions (Lusk \& Hudson, 2004).

When previous studies were consulted, it is clear that sample sizes are relatively small when conducting an experimental auction. Cunningham (2003) used a total sample size of 57 participants. Participants were split into five groups of 10 and one group of 7 . The study tested the impact of information treatments on the willingness to pay for Bison products, using an experimental auction. In the study of Lusk, Feldkamp \& Schroeder (2004), two experimental groups were used with 28 and 27 participants respectively. The objective of this study was to use an incentive compatible method where consumers would reveal their true value for a 'generic' steak versus a steak with specific attributes, thus only participants' willingness to pay was tested.

The sample size for the experimental procedure consisted of 31 participants, all residing in the Eastern suburbs of Pretoria, Gauteng. Approximately 60 participants were invited (using convenience sampling) to take part in the auction with 31 of them accepting the invitation and attending the auction. Participants for this study had to be regular consumers of sheep meat, be the main buyers of groceries in the household and be from the wealthier consumer segments as measured by the Living Standard Measure (LSM) market segmentation classification developed by the South African Advertising Research Foundation (SAARF) (www.saarf.co.za). Participants for this study had to form part of the consumers in LSM groups $8-10$ being affluent enough to potentially afford sheep meat with it being an expensive red meat option. Furthermore, when asking people to bid on an additional credence attribute, it is likely that only the wealthier consumers would be willing or able to pay a premium on an already expensive, luxurious product.

\subsection{Experimental Procedure}

The experimental procedure consisted of a one-day pre-survey and experimental auction. On arrival, participants then received an auction hamper containing the following: a block of fudge, booklet with bidding slips, R200 cash, a random ID number and written auction instructions. Real money was given to participants as part of an attempt to create a more realistic experiment, as supported by Horowitz \& McConnell (2002). 
Subjects were asked to fill out a pre-auction survey. Once all the pre-surveys were collected, the random $n$ th-price auction began. A practice auction with blocks of fudge was held before the actual auction for Karoo lamb was conducted in order to allow participants to get some practice using the mechanism (similar to Melton, Huffman, Shogren \& Fox, 1996; Cunningham, 2003; Giamalva, Bailey \& Redrern, 1997).

After the fudge auction, the facilitator explained that the actual auction for Karoo lamb would now start. The auction consisted of six bidding rounds and only one of these rounds would be randomly drawn to determine the binding round. It was further explained that the binding round would be determined after the sixth round by the role of a dice. Once again it was mentioned that because the binding round is randomly determined, it is in the bidders' best interest to bid sincerely in every round. The participants were asked to bid in R1 increments in order to simplify the exchange process.

An unmarked packet of approximately $500 \mathrm{~g}$ of lamb loin chops (base product) was sent around the participants. The chops were packed in a cellophane tray with clear wrap to make the product completely visible to the audience. Participants were told that they each already had a similar packet of chops to take home, but that it was stored in the kitchen fridge at the facility due to the perishable nature of the product. A second similar 500g packet of lamb loin chops was sent around, the only difference in the product being that the second packet of chops were marked with a prototype label "Karoo lamb" (below), because the actual Karoo meat of origin label was not finalised at that stage.

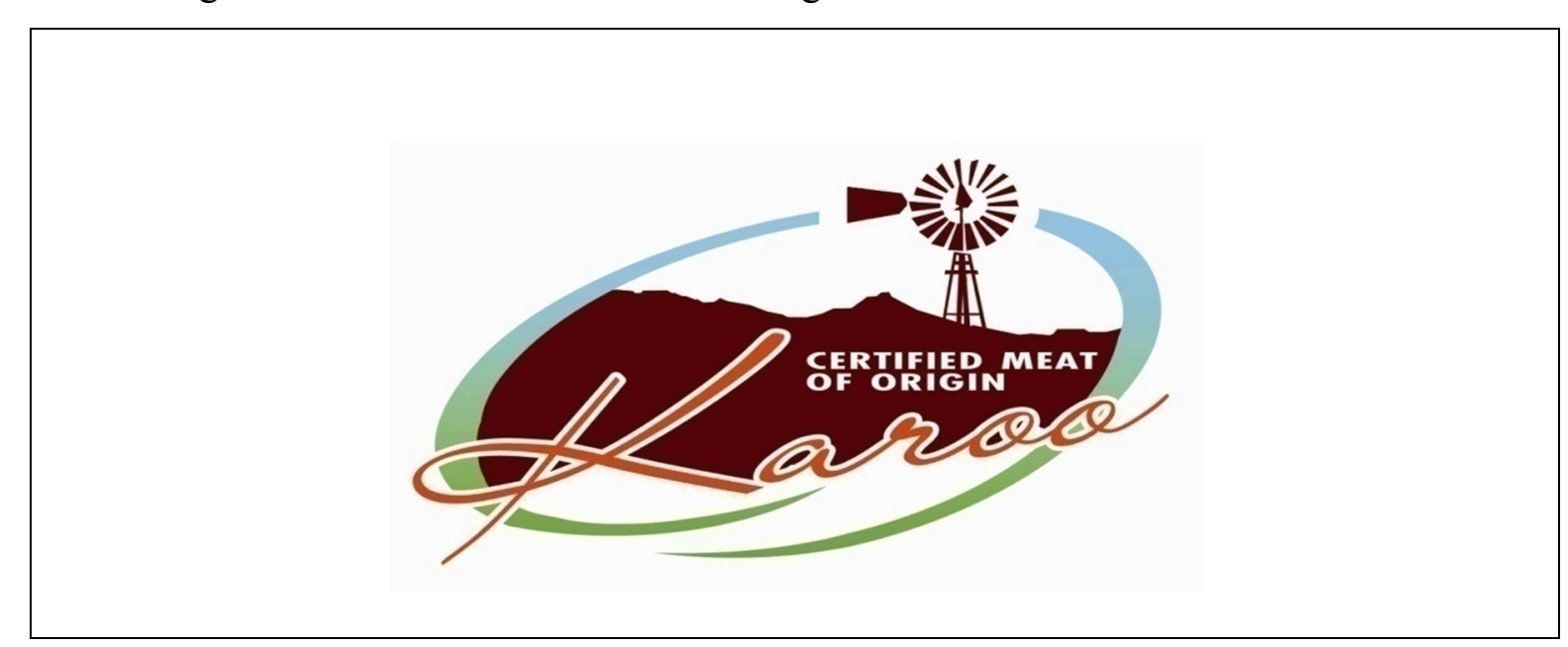

Figure 1: First prototype certification mark for Karoo meat of origin 
Participants were then asked to place a bid to upgrade the base product to the product certified as Karoo lamb. There was no limit as to what they could bid, i.e. no monetary constraint was placed on bidders. One can argue that there are some monetary constraints, but with the product having a market value of approximately R50 and participants being endowed with R200 as compensation for attending the auction and bidding money, any participant could easily bid four times the market value of the base product as a premium on the base product, however, this would be a highly unlikely scenario. If participants wished to bid more than R200 as the premium, they would have the option to pay the difference from their own pocket (as would be the realistic market situation). No verbal or written constraints on bids were placed during the auction.

It is important to note that participants were only bidding their willingness to pay a premium above current retail prices for 'generic' South African lamb. The study thus aims to assess the value of clearly identifying and market a meat product of origin for the consumer, similar to studies done by Alfnes \& Rickertsen (2003) and Evans, Brown, Collins, D’Souza, Rayburn $\&$ Sperow (2008) where consumers' willingness to pay for meat of origin was tested using an experimental auction. There are two options when considering the procedure to elicit the demand for a novel product. Subjects can either be endowed with a good and asked how much they are willing to pay to upgrade the original good to a novel good with similar but somewhat different attributes; or they can simply bid on the full value of the novel good (Lusk, Feldkamp \& Schroeder, 2004).

The reason, in this specific experiment, for not bidding on the entire product is to simplify data analysis. As explained in the study by Corrigan, Depositario, Nayga, Wu, \& Laude (2009), if participants only bid on the product, the bidding value can be taken as the premium a participant is willing to pay for the additional attribute. Where participants bid on the entire product and their market value for the base product is not known, it would be complicated to extract the WTP estimate for the additional product attribute. A further reason is that the specific product in this auction is only an 'upgraded' version of an existing product which is well known to participants. The value that participants attach to the base product is not known, because market prices for the base product were not given to participants; the researcher cannot state the exact reference price used by participants in this experiment. It thus simplifies the procedure to simply bid on a premium amount for the upgraded product. 
All the bids were collected and sorted from the highest to the lowest bid. A random number (n) was drawn to determine the cut-off position indicating the market clearing price. A random $n$ is drawn from the distribution between 2 and the number of participants $(\mathrm{k})$. This random number allocates the position which will in turn determine the cut-off price (also referred to as the payment- or market clearing price). To explain, if the random number $n$ is 19, the price at the nineteenth position is taken as the cut-off price. Every bid above the cutoff price wins the auction. If there are bids in positions above random number 19 with the same price as position 19, they would be grouped together with the random number position and would not win the auction.

The reason for a position being drawn and not a random price is as follows: If a price is drawn, then there would be limitations on what could be the winning price. The monitor would have to decide on a band for the prices that could be possible cut-off prices. On the other hand, if a position is drawn, bidding prices are not influenced by the monitor at all and are completely random and original.

The winning participants ID numbers are revealed as well as the random number (position) and the payment price. This information can be used to monitor the mechanism to prove that truthful bidding is the best strategy.

For a second time, participants had to write their maximum willingness to pay to exchange the generic lamb loin chops for the certified Karoo lamb loin chops, while taking the revealed information from the first bidding round into consideration. The reason for repeated rounds is that participants only realize that it is the best strategy to bid truthfully after a few rounds of bidding (Melton, Huffman, Shogren, Fox, 1996). Repeated rounds were done is most of the experimental literature analysed for this study (Melton, Huffman, Shogren, \& Fox, 1996; Giamalva, Bailey \& Redfern, 1997; Cunningham, 2003; Noussair, Robin \& Ruffieux, 2004).

In the second round of bidding for Karoo lamb, additional information about the label was given to participants in the form of an information sheet (Box 1). Participants were given time to read through the information hand-out on Karoo Meat before asked to bid the maximum amount they were willing to pay to exchange their originally endowed lamb loin chops for the certified Karoo lamb loin chops. 


\section{Box 1: Karoo information sheet}

\section{Where is the Karoo?}

Traditionally the Karoo is the great semi-arid area stretching North-eastwards from the Cape.

\section{Some requirements to conform to in order to be labelled as Karoo meat:}

Only animals originating from the Karoo or animals that remained in the area of the Karoo at least 12 months before slaughter and which is free of scheduled diseases can be labelled as Karoo meat.

Animals should have free access to sufficient amounts of cold, fresh, clean water meeting the requirements of drinking animals. The animals should also have free access to natural veldt grazing. Supplementary feeding is permitted in times of drought.

\section{Karoo Lamb as a brand:}

“Windmills, sheep, farm homesteads, endless vistas, home-baked bread..."

The 'Karoo' concept has become synonymous with quality, tradition and wholesomeness. A South African treasure: flocks of sheep, grazing freely amongst scattered shrubs. "Their meat is spiced on the hoof and described as mouth-watering succulent." No surprise, these sheep feed on a thousand different species of wild herbs - the most exquisite lamb, worldrenowned as free-range Karoo Lamb.

Source: J.F. Kirsten, D. Troskie, H. Vermeulen, H. Schönfeldt and C. Bramley. The potential of Karoo Lamb as origin based meat and Geographical Indication - University of Pretoria, 2008

Participants were asked to take a holistic view of the auction procedures thus far and take all relevant information into account before submitting their next bid. Once again they had to write their maximum willingness to pay to exchange the generic lamb chops for the certified Karoo lamb chops. For the second time, participants were to receive additional information about Karoo lamb. In this step of the proceedings, participants were presented with a PowerPoint-supported presentation by Prof. Hettie Schönfeldt, a nutritionist and animal scientist who was actively involved in the sensory research on Karoo lamb preceding the experimental auction. The presentation covered research done on sensory differences between mutton produced in different regions in South Africa and Namibia, and further compared fatty acid profiles of mutton from different regions with that of the Karoo region. It is important to note that all information given to participants were factual and not leading them in any favourable or non-favourable way to bid in a specific way. 
Two more bidding rounds followed the presentation; where after a binding round was drawn. The monitor used a six-sided dice to determine the binding round for the Karoo lamb auction. The final auction winners were revealed. The winners of the auction were taken aside and the exchange for the novel product (certified Karoo lamb chops) was made where the winners then paid the payment price for the exchange in products.

Data analysis was conducted in SPSS 12.0. Statistical test consisted mainly of descriptive statistics, one-way analysis of variance (ANOVA) tests and Chi-square testing to explore difference between bidding rounds and sub-groups within the sample.

\section{Results \& Discussion}

\subsection{Consistency between duplicate bidding rounds}

Table 1 presents a summary of the results of average bids of each of the six bidding rounds as well as grouped bids within each information treatment group. The standard deviation of each average bid as well as any possible statistical significant difference between these bids are summarised in Table 1.

First, a one-way ANOVA test was done on the grouped bids to check for consistency between the duplicate bidding rounds within each of the three information treatments, i.e. to see if there is any statistical significant difference between rounds one and two; rounds three and four and rounds five and six. No significant difference was found with a p-value $>0.1$ in all three cases. These results thus indicate that the average sample bids were consistent and justify the further use of an average between the duplicate rounds within the various information treatments in further analyses. Thus, the average bids from rounds one and two; rounds three and four and rounds five and six were then grouped together to form only three average bids for further statistical analysis. It is important to note that the sample size was not increased, because then bids from the same participant would have been taken into account twice. 


\subsection{The impact of information treatments}

As mentioned earlier, an important objective of this study was to investigate the potential impact of information treatments on bidding behaviour by comparing the average bids for the various treatments (as shown in Table 1).

As evident from Table 1, there was a significant difference $(f=9,199 ; \mathrm{df}=2 ; \mathrm{p}=0.004)$ between bidding round one, where participants were only exposed to the Karoo lamb label and bidding round two, where participants were further exposed to the Karoo lamb information sheet. From the average bids recorded, the biggest impact of information treatments on bidding behaviour was after the exposure to the Karoo information sheet, with an average increase of $55 \%$ in the premium participants are willing to pay. This result serves as an implication that printed media can have a significant positive impact on consumers' willingness to pay for Karoo lamb.

There was also a significant difference $(f=9,199 ; \mathrm{df}=2 ; \mathrm{p}=0.000)$ between round one (exposure to Karoo lamb label) and round three (exposure to Karoo lamb presentation) with a $77 \%$ increase in premiums, thus capturing the combined effect of both additional information treatments introduced in the auction proceedings. It is important to note that there was no significant difference between round two (exposure to Karoo lamb information sheet) and round three (exposure to Karoo lamb presentation). Thus, the presentation did not add significant value to participants' bidding behaviour. An increase in average bids of only $15 \%$ was observed, which is not regarded as a significant increase. 
Table 1: Average bidding amounts during the experimental auction for a $500 \mathrm{~g}$ packet of loin lamb chops certified as meat form the

\begin{tabular}{|c|c|c|c|c|c|c|c|}
\hline \multirow{2}{*}{$\begin{array}{l}\text { Bidding } \\
\text { round: }\end{array}$} & \multirow{2}{*}{$\begin{array}{c}\text { Information } \\
\text { Treatment }\end{array}$} & \multicolumn{3}{|c|}{ Individual bidding rounds: } & \multicolumn{3}{|c|}{ Information treatments: } \\
\hline & & $\begin{array}{c}\text { Average } \\
\text { premium } \\
\text { price bid } \\
(\mathrm{R} / \mathbf{k g})\end{array}$ & $\begin{array}{l}\text { Standard } \\
\text { Deviation }\end{array}$ & $\begin{array}{l}\text { Significant } \\
\text { Differences }\end{array}$ & $\begin{array}{c}\text { Average } \\
\text { premium price } \\
\text { bid }(\mathrm{R} / \mathrm{kg})\end{array}$ & $\begin{array}{l}\text { Standard } \\
\text { Deviation }\end{array}$ & $\begin{array}{l}\text { Significant } \\
\text { differences: }\end{array}$ \\
\hline Round 1 & $\begin{array}{l}\text { Exposure to } \\
\text { Karoo lamb label }\end{array}$ & $\mathrm{R} 16.52 / \mathrm{kg}$ & 7.742 & $\begin{array}{l}\text { None, } \\
{[f=0.7676,}\end{array}$ & $\mathrm{R} 15.12 / \mathrm{kg}(\mathrm{a})$ & 5.266 & $\begin{array}{l}\text { Significant differences } \\
{[f=9.199, \mathrm{df}=2,} \\
\mathrm{p}<0.000]\end{array}$ \\
\hline Round 2 & & $\mathrm{R} 13.74 / \mathrm{kg}$ & 4.225 & $\mathrm{df}=1 ; \mathrm{p}>0.1]$ & & & $\begin{array}{l}\text { Between } \\
a \& b(p=0.004) \\
a \& c(p=0.000)\end{array}$ \\
\hline Round 3 & $\begin{array}{l}\text { Exposure to } \\
\text { Karoo lamb } \\
\text { information sheet }\end{array}$ & $\mathrm{R} 21.42 / \mathrm{kg}$ & 5.113 & $\begin{array}{l}\text { None, } \\
{[f=1.832,}\end{array}$ & $\mathrm{R} 23.38 / \mathrm{kg}(\mathrm{b})$ & 5.443 & $\begin{array}{l}\text { No significant } \\
\text { difference was found }\end{array}$ \\
\hline Round 4 & & $\mathrm{R} 25.36 / \mathrm{kg}$ & 6.274 & $\mathrm{df}=1 ; \mathrm{p}>0.1]$ & & & $(p=0.219)$ \\
\hline Round 5 & $\begin{array}{l}\text { Exposure to } \\
\text { Karoo lamb }\end{array}$ & $\mathrm{R} 26.58 / \mathrm{kg}$ & 5.878 & None, & $\mathrm{R} 26.88 / \operatorname{kg}(\mathrm{c})$ & 5.879 & \\
\hline Round 6 & & $\mathrm{R} 27.16 / \mathrm{kg}$ & 5.949 & $\mathrm{df}=1 ; \mathrm{p}>0.1]$ & & & \\
\hline
\end{tabular}




\subsection{Mean bids linked to demographic variables}

The purpose of this section is to explore the demographic backgrounds of participants and if it has an effect on the bidding behaviour observed in the experimental auction. Only the most significant variables (age and gender) are discussed in this paper, as no statistically significant differences were observed for household income level, education level or household size.

The data presented in the tables below generally illustrates the absence of significant differences, when considering the bidding behaviour of demographic sub-groups in the sample. Certain demographic sub-groups presented with higher average bids, but the majority of these differences were statistically insignificant. A possible explanation for this unusual absence of significant differences in terms of demographic variables could be related to the sample size $(n=31)$ being relatively small when considering statistical analysis. When the sample size increases there is actually more information to analyse (the values of more random variables). One can expect the sample mean to be closer to the population mean, the quantity intended to estimate. Thus, one would be able to have a more accurate analysis of means, being able to decide if the differences among sample means can be attributed to chance, or whether it is real differences between the means of the population sampled (Freud, 1992).

When bids were split into age groups (Table 2), it was found that older participants $(>40)$ were bidding higher premiums, especially in the initial bid and after exposure to the information sheet (29\% and 35\% higher respectively) compared to younger participants. However, no statistical significant difference was found between auction bids and age groups which are most likely linked to the limited sample size as explained previously. It could be argued that images related to the Karoo could awaken nostalgia of days gone by, especially for older participants potentially more exposed to the traditional Karoo concepts, thus motivating them to bid higher premiums for Karoo lamb than their younger counterparts. 
Table 2: $\quad$ Mean bids linked to age

\begin{tabular}{|c|c|c|c|c|c|}
\hline Variable & $\begin{array}{c}\text { Experimental } \\
\text { Treatment }\end{array}$ & $\begin{array}{c}\text { Variable } \\
\text { Levels }\end{array}$ & $\begin{array}{c}\text { Percentage } \\
\text { of Total } \\
\text { Sample } \\
(n=31)\end{array}$ & $\begin{array}{c}\text { Mean Bid } \\
(\mathbf{R} / \mathbf{k g})\end{array}$ & $\begin{array}{l}\text { Significant } \\
\text { Difference }\end{array}$ \\
\hline $\begin{array}{l}\text { Age } \\
\text { Initial bid }\end{array}$ & $\begin{array}{l}\text { Exposure to } \\
\text { Karoo lamb } \\
\text { label }\end{array}$ & $\begin{array}{l}\text { up to } 40 \\
\text { years } \\
>40 \text { years }\end{array}$ & $\begin{array}{l}45.2 \% \\
54.8 \%\end{array}$ & $\begin{array}{l}\mathrm{R} 11.92 / \mathrm{kg} \\
\mathrm{R} 17.76 / \mathrm{kg}\end{array}$ & $\begin{array}{c}\text { None: } \\
{[f=2.473 ; \mathrm{df}=1 ;} \\
\mathrm{p}>0.1]\end{array}$ \\
\hline $\begin{array}{l}\text { Bid after } \\
\text { info sheet }\end{array}$ & $\begin{array}{l}\text { Exposure to } \\
\text { Karoo lamb } \\
\text { information } \\
\text { sheet }\end{array}$ & $\begin{array}{l}\text { up to } 40 \\
\text { years } \\
>40 \text { years }\end{array}$ & $\begin{array}{l}45.2 \% \\
54.8 \%\end{array}$ & $\begin{array}{l}\mathrm{R} 20.22 / \mathrm{kg} \\
\mathrm{R} 26.00 / \mathrm{kg}\end{array}$ & $\begin{array}{c}\text { None: } \\
{[f=2.260 ; \mathrm{df}=1 ;} \\
\mathrm{p}>0.1]\end{array}$ \\
\hline $\begin{array}{l}\text { Bid after } \\
\text { talk }\end{array}$ & $\begin{array}{l}\text { Exposure to } \\
\text { Karoo lamb } \\
\text { presentation }\end{array}$ & $\begin{array}{l}\text { up to } 40 \\
\text { years } \\
>40 \text { years }\end{array}$ & $\begin{array}{l}45.2 \% \\
54.8 \%\end{array}$ & $\begin{array}{l}\mathrm{R} 28.28 / \mathrm{kg} \\
\mathrm{R} 25.70 / \mathrm{kg}\end{array}$ & $\begin{array}{c}\text { None } \\
{[f=0.362 ; \mathrm{df}=1 ;} \\
\mathrm{p}>0.1]\end{array}$ \\
\hline
\end{tabular}

In general, female respondents presented higher bids than male respondents. For the auction bids after participants were exposed to the Karoo lamb information sheet, a statistical significant difference $(f=3.370 ; \mathrm{df}=1 ; \mathrm{p}=0.077)$ was observed when comparing average bids to gender. A possible explanation could be that generally, females do more grocery shopping than men (Katsaras, Wolfson, Kinsey, \& Senauer, 2001) and could indicate that female shoppers are more aware of current market prices and premiums on specific products. When taking the general romantic image of the Karoo into consideration, it is possible that female respondents are more emotional and nostalgic towards the idea of the Karoo, causing them to be willing to pay a higher premium for meat from this region. Lastly, from a statistical viewpoint, $80 \%$ of the participants in this sample were female, which could cause a distorted picture, although generally most of the grocery shopping is done by females, as mentioned above. 
Table 3: $\quad$ Mean bids linked to gender

\begin{tabular}{|c|c|c|c|c|c|}
\hline Variable & $\begin{array}{c}\text { Experimental } \\
\text { Treatment }\end{array}$ & $\begin{array}{l}\text { Variable } \\
\text { Levels }\end{array}$ & $\begin{array}{c}\text { Percentage } \\
\text { of Total } \\
\text { Sample } \\
(n=31)\end{array}$ & $\begin{array}{c}\text { Mean Bid } \\
(\mathbf{R} / \mathbf{k g})\end{array}$ & $\begin{array}{l}\text { Significant } \\
\text { Difference }\end{array}$ \\
\hline $\begin{array}{l}\text { Gender } \\
\text { Initial bid }\end{array}$ & $\begin{array}{l}\text { Exposure to } \\
\text { Karoo lamb } \\
\text { label }\end{array}$ & $\begin{array}{l}\text { Male } \\
\text { Female }\end{array}$ & $\begin{array}{l}20.0 \% \\
80.0 \%\end{array}$ & $\begin{array}{l}\mathrm{R} 11.34 / \mathrm{kg} \\
\mathrm{R} 16.04 / \mathrm{kg}\end{array}$ & $\begin{array}{c}\text { None: } \\
{\left[\begin{array}{c}{[f=0.965 ; \mathrm{df}=1 ;} \\
\mathrm{p}>0.1]\end{array}\right.}\end{array}$ \\
\hline $\begin{array}{l}\text { Bid after } \\
\text { information } \\
\text { sheet }\end{array}$ & $\begin{array}{l}\text { Exposure to } \\
\text { Karoo lamb } \\
\text { information } \\
\text { sheet }\end{array}$ & $\begin{array}{l}\text { Male } \\
\text { Female }\end{array}$ & $\begin{array}{l}20.0 \% \\
80.0 \%\end{array}$ & $\begin{array}{l}\mathrm{R} 16.34 / \mathrm{kg} \\
\mathrm{R} 25.08 / \mathrm{kg}\end{array}$ & $\begin{array}{c}\text { Yes, when } \\
\text { comparing gender } \\
\text { groups } \\
\text { Yes; [f=3.370; df=1; } \\
\text { p=0.077] } \\
\text { Male consumers - } \\
\text { bid lower at } \\
\text { R16.34/kg } \\
\text { Female consumers - } \\
\text { bid higher at } \\
\text { R25.08/kg }\end{array}$ \\
\hline $\begin{array}{l}\text { Bid after } \\
\text { talk }\end{array}$ & $\begin{array}{l}\text { Exposure to } \\
\text { Karoo lamb } \\
\text { presentation }\end{array}$ & $\begin{array}{l}\text { Male } \\
\text { Female }\end{array}$ & $\begin{array}{l}20.0 \% \\
80.0 \%\end{array}$ & $\begin{array}{l}\mathrm{R} 22.16 / \mathrm{kg} \\
\mathrm{R} 28.00 / \mathrm{kg}\end{array}$ & $\begin{array}{c}\text { None: } \\
{[f=1.199 ; \mathrm{df}=1 ;} \\
\mathrm{p}>0.1]\end{array}$ \\
\hline
\end{tabular}

3.2 Mean bids linked to Karoo lamb purchasing behaviour

In this section, the average bids obtained in the experimental auction were compared to Karoo lamb purchasing behavioural factors captured in the survey questionnaire. Again, only some of the important results are discussed in this paper. The results are presented in Table 4.

Upon analysing the bidding results, it was found that participants who have bought the product before bid higher than participants who have not bought Karoo lamb before. This positive impact of previous purchases on bidding behaviour is supported by a statistically significant difference found after the first bidding round $(f=2.912, \mathrm{df}=1 ; \mathrm{p}=0.099)$ with a $90 \%$ level of significance and also after the second round of bidding $(f=7.053, \mathrm{df}=1 ; \mathrm{p}=0.013)$ with a $95 \%$ level of significance. This result could be interpreted as an indication of a general 
positive experience from previous purchases of Karoo lamb, leading to an increased willingness to pay a premium for the certification of Karoo lamb.

Participants who indicated that they have not bought Karoo lamb before were asked to state the reasons for not buying Karoo lamb. The two main reasons that came to light was that it was either unavailable or that the participant did not trust the authenticity of the product.

Participants who have trust issues regarding the product's authenticity, bid lower in the first two bidding rounds than participants who did not buy the product due to a lack of availability. A statistical significant difference was found $(\mathrm{f}=4.166, \mathrm{df}=2 ; \mathrm{p}=0.026)$ after the first information treatment, supporting this statement at a 95\% level of significance. From this observation, it is clear to see that participants are reluctant to buy the product due to the lack of certification guaranteeing the products' authenticity as Karoo lamb. It was found that in the third bidding round (after both information treatments) participants with trust issues regarding product authenticity, bid slightly higher than participants not buying the product due to the lack of availability. This could serve as an indication of the positive impact of the certification and information regarding the proposed Karoo lamb label. Furthermore, a major marketing opportunity was identified from this analysis relating to the certification and proper distribution of the product. 
Table 4: Mean bids linked to Karoo lamb purchasing behaviour

\begin{tabular}{|c|c|c|c|c|c|}
\hline \multirow[t]{2}{*}{ Variable } & \multirow[t]{2}{*}{$\begin{array}{c}\text { Experimental } \\
\text { Treatment }\end{array}$} & \multirow{2}{*}{$\begin{array}{c}\text { Sample } \\
\text { Frequency } \\
\quad(\mathbf{n}=\mathbf{3 1})\end{array}$} & \multicolumn{2}{|c|}{$\begin{array}{c}\text { Mean Bid } \\
(\mathrm{R} / \mathrm{kg})\end{array}$} & \multirow[t]{2}{*}{ Significant Difference } \\
\hline & & & Yes & No & \\
\hline $\begin{array}{l}\text { Bought Karoo } \\
\text { lamb before } \\
\text { Initial bid }\end{array}$ & $\begin{array}{l}\text { Exposure to } \\
\text { Karoo lamb } \\
\text { label }\end{array}$ & $64.5 \%$ & $\mathrm{R} 17.46 / \mathrm{kg}$ & $\begin{array}{l}\mathrm{R} 10.90 / \mathrm{k} \\
\mathrm{g}\end{array}$ & $\begin{array}{l}\text { Yes; }[f=2.912, \mathrm{df}=1 ; \\
\text { p=0.099] } \\
\text { Participants who have } \\
\text { bought Karoo Lamb before } \\
\text { bid higher than those who } \\
\text { have not bought it before. }\end{array}$ \\
\hline $\begin{array}{l}\text { Bid after info } \\
\text { sheet }\end{array}$ & $\begin{array}{l}\text { Exposure to } \\
\text { Karoo lamb } \\
\text { information } \\
\text { sheet }\end{array}$ & $64.5 \%$ & $\mathrm{R} 26.90 / \mathrm{kg}$ & $\begin{array}{c}\mathrm{R} 17.00 / \mathrm{k} \\
\mathrm{g}\end{array}$ & $\begin{array}{l}\text { Yes; }[f=7.053, \mathrm{df}=1 ; \\
\qquad \mathrm{p}=0.013] \\
\text { Participants who have } \\
\text { bought Karoo Lamb before } \\
\text { bid higher than those who } \\
\text { have not bought it before. }\end{array}$ \\
\hline Bid after talk & $\begin{array}{l}\text { Exposure to } \\
\text { Karoo lamb } \\
\text { presentation }\end{array}$ & $64.5 \%$ & $\mathrm{R} 28.96 / \mathrm{kg}$ & $\begin{array}{c}\mathrm{R} 23.10 / \mathrm{k} \\
\mathrm{g}\end{array}$ & $\begin{array}{c}\text { None: } \\
{[f=1.810, \mathrm{df}=1 ; \mathrm{p}>0.1]}\end{array}$ \\
\hline \multirow[t]{2}{*}{$\begin{array}{l}\text { No, why not? } \\
\text { Initial bid }\end{array}$} & \multirow[t]{2}{*}{$\begin{array}{l}\text { Exposure to } \\
\text { Karoo lamb } \\
\text { label }\end{array}$} & \multirow{2}{*}{$\begin{array}{l}\text { Availability: } \\
81.8 \% \\
\text { Trust: } \\
18.2 \%\end{array}$} & Availability & $\begin{array}{l}\text { Trust } \\
\text { Issues }\end{array}$ & \multirow[t]{2}{*}{$\begin{array}{c}\text { None: } \\
{[f=1.853, \mathrm{df}=2 ; \mathrm{p}>0.1]}\end{array}$} \\
\hline & & & $\mathrm{R} 12.22 / \mathrm{kg}$ & $\mathrm{R} 5.00 / \mathrm{kg}$ & \\
\hline $\begin{array}{l}\text { Bid after info } \\
\text { sheet }\end{array}$ & $\begin{array}{l}\text { Exposure to } \\
\text { Karoo lamb } \\
\text { information } \\
\text { sheet }\end{array}$ & $\begin{array}{l}\text { Availability: } \\
81.8 \% \\
\text { Trust: } \\
18.2 \%\end{array}$ & $\mathrm{R} 18.56 / \mathrm{kg}$ & $\begin{array}{l}\mathrm{R} 10.00 / \mathrm{k} \\
\mathrm{g}\end{array}$ & $\begin{array}{l}\text { Yes; }[f=4.166, \mathrm{df}=2 ; \\
\qquad \mathrm{p}=0.026] \\
\text { Participants who have a trust } \\
\text { issue with whether a product } \\
\text { is authentic Karoo Lamb, } \\
\text { bid lower than people whose } \\
\text { reason for not buying the } \\
\text { product is lack of } \\
\text { availability }\end{array}$ \\
\hline Bid after talk & $\begin{array}{l}\text { Exposure to } \\
\text { Karoo lamb } \\
\text { presentation }\end{array}$ & $\begin{array}{l}\text { Availability: } \\
81.8 \% \\
\text { Trust: } \\
18.2 \%\end{array}$ & $\mathrm{R} 22.66 / \mathrm{kg}$ & $\begin{array}{c}\mathrm{R} 25.00 / \mathrm{k} \\
\mathrm{g}\end{array}$ & $\begin{array}{c}\text { None: } \\
{[f=0.908, \mathrm{df}=2 ; \mathrm{p}>0.1]}\end{array}$ \\
\hline
\end{tabular}




\section{Conclusion}

The results from the random $n$ th-price auction were investigated and the average premium bids for Karoo lamb were linked to the variables obtained in the pre-auction survey. An important number of observations were revealed in this paper.

Bids from the random $n$ th-price auction were grouped into only three rounds (initial round, after information sheet, after talk with PowerPoint slide-show) in order to have a clearer indication of the possible impact of information on bidding behaviour. After each information treatment, the mean WTP bids for the Karoo lamb chops increased. The bids for the premium on Karoo lamb loin chops went from R15.12/ kg to R23.20/kg to R26.88/ $\mathrm{kg}$. There are two important observations to take note of. Throughout the entire auction, most of the participants submitted a non-zero bid, indicating a general willingness to pay a premium for certified Karoo lamb. Secondly, it is important to note the dramatic increase in bids from round one to round two, followed by the more marginal increase from round two to round three. Thus, from this observation, one can conclude that basic information about Karoo lamb had a more significant impact on consumers' willingness to pay for certified Karoo lamb as meat of origin. This basic pattern was observed throughout most of the auction results.

When the average bids obtained from the auction were linked to variables, it was found that females bid generally higher than male participants, while older participants ( $>40$ years of age) submitted higher bids than younger participants.

The general lack of availability of Karoo lamb was pointed out, with approximately $82 \%$ $(n=11)$ of participants who indicated that they had not bought Karoo lamb before due to the product not being readily available. Another serious concern that was brought to light from the survey results, was that $18.2 \%(n=11)$ of participants who indicated that they had not bought Karoo lamb before was because they did not trust the authenticity of the product. Despite the obvious concerns regarding Karoo lamb, approximately $58 \%$ of the sample indicated that they are willing to pay a premium for Karoo lamb. This is a very important observation, serving as a clear indication of the possibilities for Karoo lamb to be sold and certified as meat of origin. 
From a marketing perspective, an obvious opportunity and case for intellectual property protection exists when considering the Karoo lamb case. The results from the experimental auction suggested that participants are willing to pay a premium for certified Karoo lamb, with an average bid of R21.80/kg recorded. Market prices for lamb loin chops ranged from $\mathrm{R} 89.95 / \mathrm{kg}$ to $\mathrm{R} 118.16 / \mathrm{kg}$, as observed from butcheries and supermarkets in Pretoria East in July/August 2010.

Furthermore, information treatments had a significant effect on bidding behaviour. From the increase observed (approximately 55\%) in average bids after the first basic information treatment was introduced, it is suggested that basic information will be sufficient to market certified Karoo lamb as a meat product of origin. Lastly, the concerns raised by participants about the lack of availability and authenticity of Karoo lamb indicate the need for a comprehensive distribution strategy to ensure the retail presence of Karoo lamb as a product of origin. 


\section{References}

Akaichi, F. \& Gil, J.M. 2009. Factors Explaining the Consumers' Willingness-to-Pay for a "Typical” Food Product in Spain: Evidence from Experimental Auctions. Contributed Paper prepared for presentation at the International Association of Agricultural Economists Conference, Beijing, China.

Alfnes, F. \& Rickertsen, K. 2003. European Consumers' Willingness to Pay for U.S. Beef in Experimental Auction Markets. American Journal of Agricultural Economics. Vol. 85(2). pp. 396-405.

Allaire. G. 2004. Quality in economics, a cognitive perspective. Chapter 3 in: Harvey M., McMeekin A. \& Warde A. 2004. Qualities of Food, Manchester University Press, Manchester, UK.

Bramley, C. and Kirsten, J.F. (2007). Exploring the Economic Rationale for Protecting Geographical Indicators in Agriculture. Agrekon Vol 46 (1), March 2007

Corrigan, J.R., Depositario, D.T., Nayga, R.M., Wu, X. \& Laude, T.P. 2009. Comparing Open-Ended Choice Experiments and Experimental Auctions: An Application to Golden Rice. American Journal of Agricultural Economics. Vol. 91(3): 837-853.

Cunningham, C.F. 2003. The impact of information on willingness to pay for Bison. Unpublished Masters thesis. Saskatoon: University of Saskatchewan.

Evans, J.R., Brown, C., Collins, A.R., D’Souza, G.E., Rayburn, E.B. \& Sperow, M. 2008. Determining Consumer Perceptions of and Willingness to pay for Appalachian Grass-fed Beef: An Experimental Economics Approach. Selected Paper prepared for presentation at the American Agricultural Economics Association Annual Meeting, Orlando, FL, July 27-29, 2008.

Freud, J.E. 1992. Mathematical Statistics $-5^{\text {th }}$ Edition. Prentice-Hall. New Jersey. 
Giamalva, J.N., Bailey, W.C. \& Redfern, M. 1997. An experimental study in consumers' willingness-to-pay for an irradiated meat product. Journal of Food Safety. Vol. 17: 193-202.

Horowitz, J.K. \& McConnell, K.E. 2002. A Review of WTA / WTP Studies. Journal of Environmental Economics and Management. Vol. 44: 426 - 447.

Kalish, S. \& Nelson, P. 1991. A comparison of ranking, rating and reservation price measurement in conjoint analysis. Marketing Letters. Vol. 2(4): 327-335.

Katsaras, N., Wolfson, P., Kinsey, J. \& Senauer, B. 2001. Data Mining: A Segmentation Analysis of U.S. Grocery Shoppers. Working Paper 01-01. The Retail Food Industry Center. University of Minnesota.

Kirsten, J.F. 2010. The case for a scheme to certify the origin of mutton and lamb from the "Karoo". Unpublished mimeo. University of Pretoria.

Kirsten, J.F., Troskie, D., Vermeulen, H., Schönfeldt, H. \& Bramlley, C. 2008. The potential of Karoo Lamb as origin based meat and Geographical Indication. University of Pretoria. Unpublished.

Krystallis, A. \& Ness, M. 2005. Consumer Preferences for Quality Foods from a SouthEuropean Perspective: A Conjoint Analysis Implementation on Greek Olive Oil. International Food and Agribusiness Management Review. Vol. 8(2): 62-91.

List, J.A. 2003. Using Random nth Price Auctions to Value Non-Market Goods and Services. Journal of Regulatory Economics. Vol. 23(2): 193-205.

Lusk, J.L., Feldkamp, T. \& Schroeder, T. 2004. Experimental Auction Procedure: Impact on Valuation of Quality Differentiated Goods. American Journal of Agricultural Economics. Vol. 86(2): 389-405.

Lusk, J.L. \& Hudson, D. 2004. Willingness-to-Pay Estimates and Their Relevance to Agribusiness Decision Making. Review of Agricultural Economics. Vol. 26(2):152-169. 
Lusk, J.L. \& Shogren, J.F. 2007. Experimental Auctions: Methods and Applications in Economic and Marketing Research. Cambridge: Cambridge Universal Press.

Melton, E.B., Huffman, W.E., Shogren, J.F \& Fox, A.J. 1996. Consumer Preferences for Fresh Food Items with Multiple Quality Attributes: Evidence from an Experimental Auction of Pork Chops. American Journal of Agricultural Economics. Vol. 78: 916-923.

Northen, J.R. 2000. Quality attributes and quality cues - Effective communication in the UK meat supply chain. British Food Journal. Vol. 102(3): 230-245.

Noussair, C.N., Ruffieux, B., \& Robin, S. 2004. Revealing consumers' willingness to pay: A comparison of the BDM mechanism and the Vickrey auction. Journal of Economic Psychology. Vol. 25(6): 725-741.

Oude Ophuis, P.A.M. \& Van Trijp, H.C.M. 1995. Perceived Quality: A Market Driven and Consumer Oriented Approach. Food Quality and Preference. Vol. 6: 177-183.

Padberg, D.I., Ritson, C. \& Albisu, L.M. 1997. Agro-food Marketing. New York: Cab International in association with International Centre of Advanced Mediterranean Agronomic Studies (CIHEAM).

Padilla, C., Villalobos, P., Spiller, A. \& Henry, G. 2007. Consumer Preference and Willingness to Pay for an Officially Certified Quality Label: Implications for Traditional Food Producers. Agricultura Técnica (Chile). Vol. 67(3): 300-308.

Ponte, S. \& Gibbon, P. 2005. Quality standards, conventions and the governance of global value chains. Economy and Society. Vol. 34(1):1-31.

Padilla, C., Villalobos, P., Spiller, A. \& Henrey, G. 2007. Consumer Preference and Willingness to Pay for an Officially Certified Quality Label: Implications for Traditional Food Producers.

Rodriguez, E.M.; Lupin, B. \& M.V. Lacaze, 2006. Consumers' Perceptions about Food Quality Attributes and Their Incidence in Argentinean Organic Choices. Paper presented at 
2006 Tri-Annual Meeting of the International Association of Agricultural Economists, August 12-18, 2006, Queensland, Australia. Available at: http://ideas.repec.org/p/ags/iaae06/25791.html\#biblio

Shogren, J.F., Maroglis, M., Koo, C. \& List, J.A. 2001. A random nth-price auction. Journal of Economic Behaviour \& Organization. Vol. 46: 409-421.

South African Advertising Research Foundation (SAARF). 2010. SAARF Segmentation Handbook - Based on AMPS 2008b and AMPS 2009a. Johannesburg, 2010. 